Egyptian Journal of Aquatic Biology \& Fisheries

Zoology Department, Faculty of Science,

Ain Shams University, Cairo, Egypt.

ISSN $1110-6131$

Vol. 25(2): 1053 - 1065 (2021)

www.ejabf.journals.ekb.eg

\title{
A review: The potential of microalgae as a marine food alternative in Banyuasin Estuary, South Sumatra, Indonesia
}

\author{
Angga Saputra, Redho Yoga Nugroho, Ratih Isnaini and Rozirwan* \\ Marine Science Department, Faculty of Mathematics and Natural Science, Sriwijaya University, \\ Indonesia \\ *Corresponding Author: rozirwan@unsri.ac.id
}

ARTICLE INFO

Article History:

Received: Feb. 22, 2021

Accepted: April 30, 2021

Online: May 12, 2021

Keywords:

Microalgae,

Biochemical Content,

Potential Fishing Zone,

Banyuasin Estuary

\section{ABSTRACT}

Microalgae are organisms that contain excellent nutrients as a food source. It can be used directly like supplements, medicinals, biofuels, and others. In addition, microalgae are considered a food source for fish in cultivation. This review is to describe the direct and indirect benefits of microalgae as an alternative source of seafood in Banyuasin Estuary, South Sumatra. The data used are secondary data including microalgae biodiversity and biochemical content, as well as analysis of potential fishing zones on chlorophyll- $a$ content and sea surface temperature using Aqua MODIS L-3 imagery in the same season and in different periods August 2013 and 2017. Bacillariophyceae showed the highest abundance with the Chaetoceros genus dominated of the whole observation area, where it was shown from the chlorophyll-a concentration and average sea surface temperature were optimum and stable conditions for fish growth. The Chaetoceros has great potential for development in food, medical, and bioenergy because it is high in protein, lipid, and carbohydrate content. Besides that, it can also be used as a source of food in aquaculture activities of that location.

\section{INTRODUCTION}

Microalgae, in particular those inhabiting the marine waters in Indonesia are considered as a natural resource as food supplements. Microalgae were introduced as a food source several years ago. However, the community response to this resource seems less enthusiastic due to limited information on microalgae benefits, whereas microalgae have better nutritional content than other foods in general, which should be known by the public (Novianti, 2019).

Microalgae have direct benefits for food availability because they contain fat, protein, pigments, and vitamins. The biochemical content of microalgae is a source of energy produced from the photosynthesis process (Prince and Kheshgi, 2005). These biochemical contents can be developed as pharmaceutical ingredients, cosmetics, antioxidants, and supplements (Spolaore, 2006; Tang et al., 2020). Besides, it has 
indirect benefits in the waters. Microalgae act as primary aquatic producers and become a food source for fish in the waters.

According to FAO (Food and Agriculture Organization) data in 2016, the level of fish consumption per capita in the last six years (2011-2016) has increased by $6.8 \%$. Based on 2018 KKP data, the fisheries sector contributes $50 \%$ of the total national food sources (Santoso, 2016). Banyuasin Regency, South Sumatra in 2011-2014 experienced an increase in production by $2.5 \%$, in 2011 amounting to 38,196.25 tons and in 2014 amounting to 41,149.32 tons (Banyuasin Regency Fishery, 2016). This reflects that fisheries are an important sector for national food sources. In this regard, this potential can be further enhanced with information on the potential fishing zone so that production activities are higher and more efficient. These efforts can assist fishers in fishing independently and increase fishing production (Li et al., 2021).

Therefore, this article examines the direct and indirect benefits of microalgae in their role as an alternative marine food source in Banyuasin Estuary, South Sumatra. Satellite image analysis in SST and Chlorophyll-a data can find potential fishing zones as indirect benefits and biochemical microalgae analysis as direct benefits.

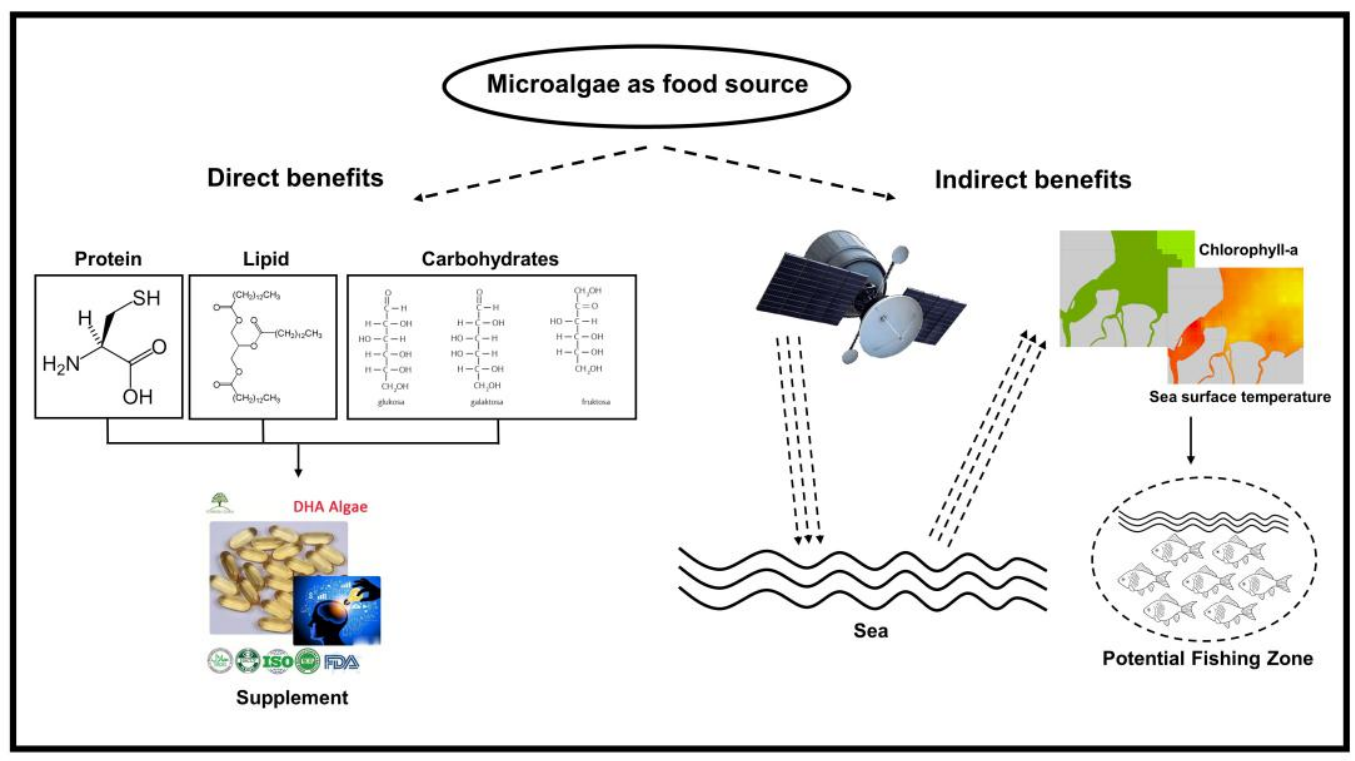

Fig. 1. Review Illustration

\section{Abundance of Phytoplankton}

There were three classes of phytoplankton dominating in Banyuasin Estuary and Musi Estuary. They were Bacillariophyceae, Cyanophyceae, Dinophyceae. Phytoplankton abundance data in Banyuasin Estuary Waters in August 2013 had a higher abundance than in Musi Estuary in August 2017 (Tabel 1).

The abundance of phytoplankton in Banyuasin Estuary in 2013 comprised Bacillariophyceae class of $26,742,859$ cell. $\mathrm{m}^{-3}$, Cyanophyceae 74,310 cell. $\mathrm{m}^{-3}$, Dinophyceae 21,585 cell. $\mathrm{m}^{-3}$, while the abundance of phytoplankton in Musi Estuary in 
2017 includes Bacillariophyceae class of 1,600,000 cell.m ${ }^{-3}$, Cyanophyceae 309,000 cell. $\mathrm{m}^{-3}$, Dinophyceae 112,000 cell. $\mathrm{m}^{-3}$. The abundance of phytoplankton showed Bacillariophyceae class, which had the highest abundance, followed by Cyanophyceae class, and the lowest abundance of Dinophyceae class.

Table 1. Abundance of phytoplankton in Banyuasin Estuary 2013 and Musi Estuary 2017

\begin{tabular}{lllll}
\hline No & Class & $\mathbf{2 0 1 3}\left(\right.$ cell.m $\left.^{-\mathbf{3}}\right)$ & $\mathbf{2 0 1 7}\left(\mathbf{c e l l . m ^ { - 3 }}\right)$ & References \\
\hline 1 & Bacillariophyceae & $26,742,859$ & $1,600,000$ & (Aryawati et al., 2017; \\
2 & Dinophyceae & 21,585 & 112,000 & Ridho, Patriono and \\
3 & Cyanophyceae & 74,310 & 309,000 & Mulyani, 2020) \\
\hline
\end{tabular}

The Bacillariophyceae class was the class that had the highest abundance compared to other classes. Bacillariophyceae class was the most common class found in waters (Nurhatika et al., 2018; Rozirwan et al., 2019). Bacillariophyceae class could adapt to water conditions (Huliselan et al., 2017; Pratama et al., 2019). Generally, the Bacillariophyceae class could respond to changing water conditions (Parakkasi et al., 2020). Bacillariophyceae class had high tolerance and adapted to environmental conditions (Aryawati et al., 2017), it was cosmopolitan. Bacillariophyceae class was more supportive of surviving longer than other classes (Armbrust, 2009). The diversity of phytoplankton species found in Banyuasin Estuary and Musi Estuary was presented in Fig. (2).

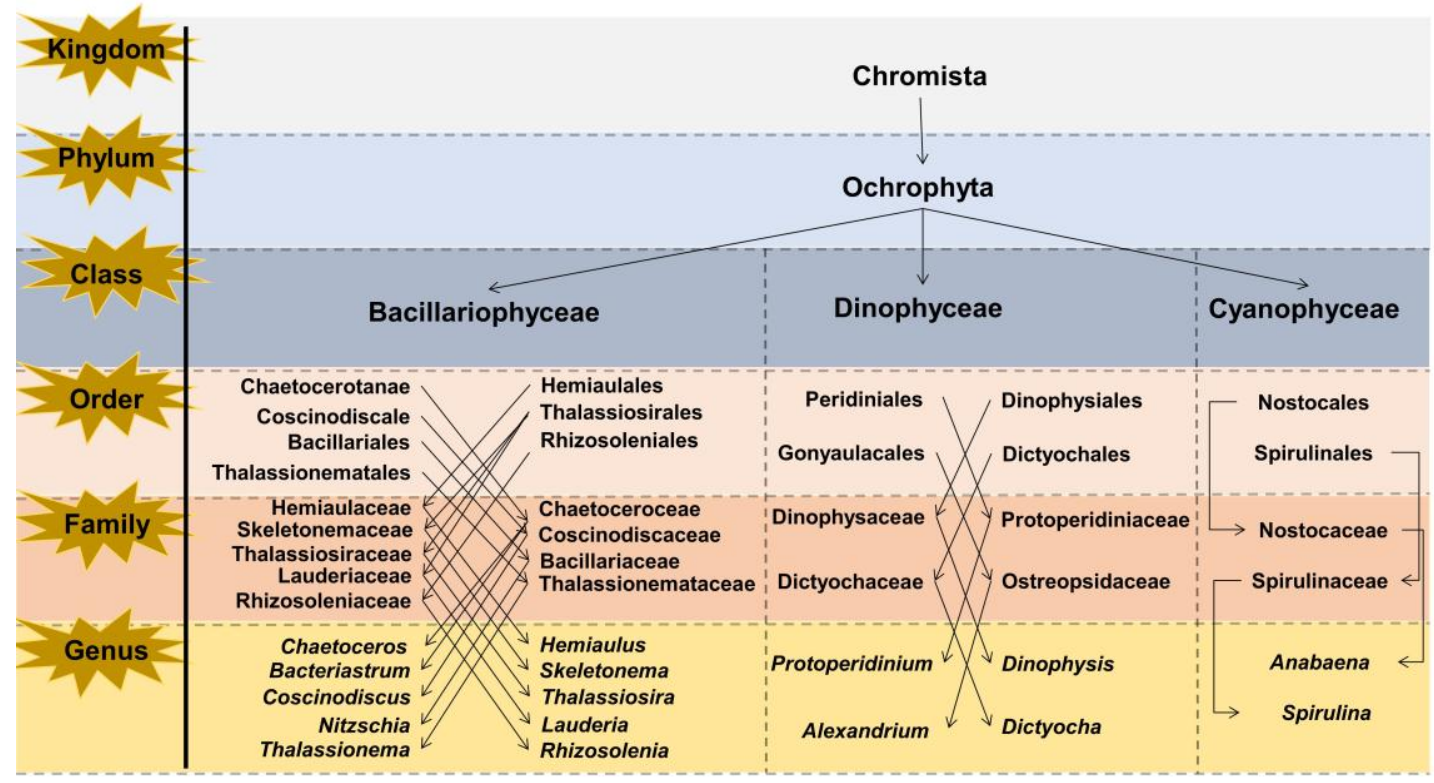

Fig. 2. Phytoplankton taxonomy in Banyuasin Estuary and Musi Estuary

Based on phytoplankton abundance data obtained in Banyuasin Estuary and Musi Estuary indicated that these waters were classified as eutrophic. Eutrophic was a water 
condition indicated by the high abundance of phytoplankton in water (Taipale $\boldsymbol{e t}$ al., 2019). According to Zhang and Wang (2020), eutrophic was a water condition with a high density of phytoplankton. Eutrophic conditions were caused by a higher concentration of nutrients in the water (Novais et al., 2018). The abundance of phytoplankton was affected by nutrients as its food source (Rozirwan et al., 2019).

Eutrophication was caused by an increase in the concentration of nutrients, such as nitrogen and phosphorus in water (Aryawati et al., 2017). Nutrients came from different sources including agriculture, stormwater, wastewater, fossil fuel combustion and anthropogenic activity (Taipale $\boldsymbol{e t}$ al., 2019). Eutrophication occured during spring and summer season, low flow water, high water residence times, sufficient light levels and high water temperature would promote rapid alga growth (Sharabian et al., 2018).

\section{Chlorophyll-a and Sea Surface Temperature}

The spatial distribution of Chlorophyll-a and Sea Surface Temperature in Banyuasin Estuary in August 2013 and 2017 was presented in Fig. (3). The spatial distribution of Chlorophyll-a concentrations in Banyuasin Estuary in August 2013 was lower than in August 2017. The range of Chlorophyll-a concentration in August 2013 was 2.8 to $9.9 \mathrm{mg} \cdot \mathrm{m}^{-3}$ (Fig. 3.A) whereas in August 2017 was 2.0 to $13.2 \mathrm{mg} . \mathrm{m}^{-3}$ (Fig. 3.B). The average Chlorophyll-a concentration fluctuation in 2013 was $5.77 \mathrm{mg} . \mathrm{m}^{-3}$, whereas in 2017 was $5.64 \mathrm{mg} \cdot \mathrm{m}^{-3}$.

The Chlorophyll-a concentrations in Banyuasin Estuary were classified into mesotrophic and eutrophic categories. Mesotrophic was a water condition with moderate fertility, whereas eutrophic had a high fertility rate (Dornhofer $\boldsymbol{e t}$ al., 2018). According to Suhadha and Asriningrum (2020), mesotrophic was a water condition with a Chlorophyll-a concentration ranged 2.0 to $5.0 \mathrm{mg} . \mathrm{m}^{-3}$, while eutrophic was 5.0 to 15 mg. $\mathrm{m}^{-3}$. The value of Chlorophyll- $a$ concentration $>1 \mathrm{mg} \cdot \mathrm{m}^{-3}$ were classified as high concentration (Wicaksono et al., 2019).

Based on the explanation above, these waters were perfect for fish survival because Chlorophyll-a concentration was getting higher. Chlorophyll-a was an essential parameter in the food chain system in waters. Therefore, Chlorophyll-a affected phytoplankton as a primary producer in waters (Purwanto et al., 2020).

According to Chen et al. (2017), Chlorophyll-a was a vital component used as the leading indicator to estimate primary water productivity. As a primary producer, these organisms converted inorganic materials into organic materials through the photosynthesis process. Therefore, chlorophyll content in water used as a fixed stock of phytoplankton indicated primary water productivity (Ridho et al., 2020).

Chlorophyll-a was an organic product of phytoplankton that had a proportional relationship with fish abundance. Water fertility could be seen from Chlorophyll-a concentration in water, which was also one of the parameters predicting the potential fishing zone with $80 \%$ success (Suhadha and Asriningrum, 2020). The fish distribution could be predicted from Chlorophyll-a concentration in water, and it was often used to 
determine potential fishing zones (Nurdin et al., 2017). According to Syah et al. (2020), Chlorophyll- $a$ was a factor that can provide a direct indication of the fish presence and fish migration pathways. There was a relationship between catching and Chlorophyll-a concentration. Getting higher Chlorophyll-a concentration was followed by getting higher fish catching (Purwanto et al., 2020).

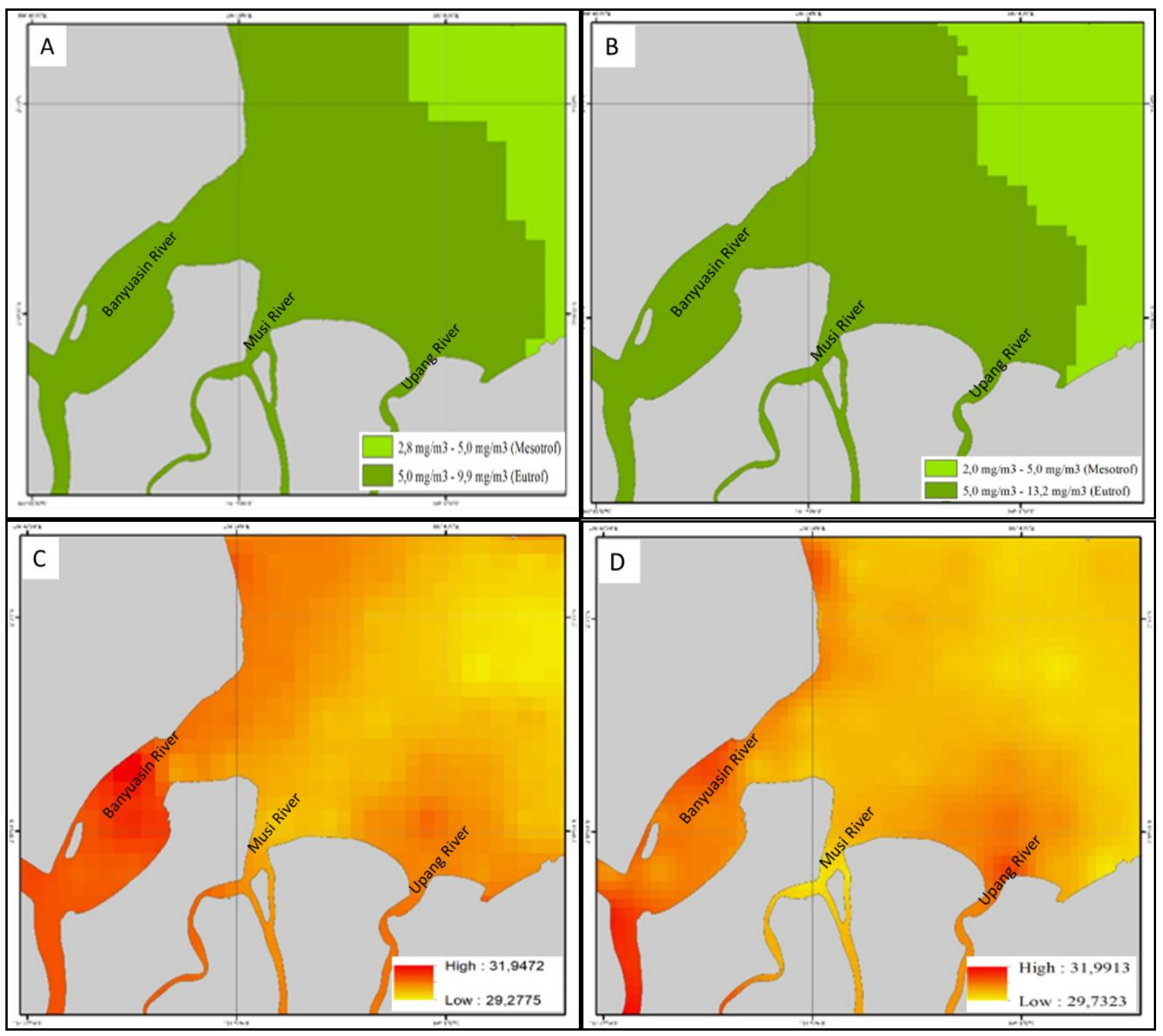

Fig. 3. Spatial distribution of Chlorophyll- $a$ and SST in the Banyuasin Estuary, A) Chlorophyll-a August 2013; B) Chlorophyll-a August 2017; C) SST August 2013; and D) SST August 2017.

\section{Source: oceancolor.gsfc.nasa.gov}

The distribution of Sea Surface Temperature in Banyuasin Estuary Waters in two periods was relatively the same. The spatial distribution of Sea Surface Temperature in August 2013 ranged from 29.2 to $31.9^{\circ} \mathrm{C}$ (Fig. 3.C), and in August 2017 of 29.7 to $31.9^{\circ} \mathrm{C}$ (Fig. 3.D). The fluctuation in the average Sea Surface Temperature in Banyuasin Estuary in 2013 was $30.2^{\circ} \mathrm{C}$, and in 2017 was $30.6^{\circ} \mathrm{C}$. 
The value of Sea Surface Temperature in this water was included in optimum conditions for biota survival. Based on the Environment Ministry's water quality standards, the temperature value in the optimum category for biota growth ranged from 28 to $32^{\circ} \mathrm{C}$. According to Ridho et al. (2020) optimum temperature range for plankton growth was between 20 to $30^{\circ} \mathrm{C}$. Sea Surface Temperature could be used as an indicator and significantly affects fish presence (Dutta et $\boldsymbol{a l}$., 2016).

Sea Surface Temperature was an important variable in controlling fish populations in water (Solanki et al., 2010). According to Wicaksono et al. (2019), temperature parameter was used as an indicator in determining the presence of fish. Sea Surface Temperature could affect upwelling, which carries nutrients from bottom to surface that can be a feeding ground for fish. Sea Surface Temperature could also be used in determining the thermal front area that was defined as an encounter of warm and cold water masses. The front formed was a trap of nutrients to become a feeding ground for fish (Wijesekera et al., 2016).

\section{Potential Fishing Zones}

The distribution of fishing potential zone points in the Banyuasin Estuary was presented in Fig. (4). Determination of potential fishing ground based on the distribution of Chlorophyll-a and Sea Surface Temperature in Banyuasin waters. The distribution of fishing potential zone points in two periods was higher in a direction outside Banyuasin and Musi Estuary.

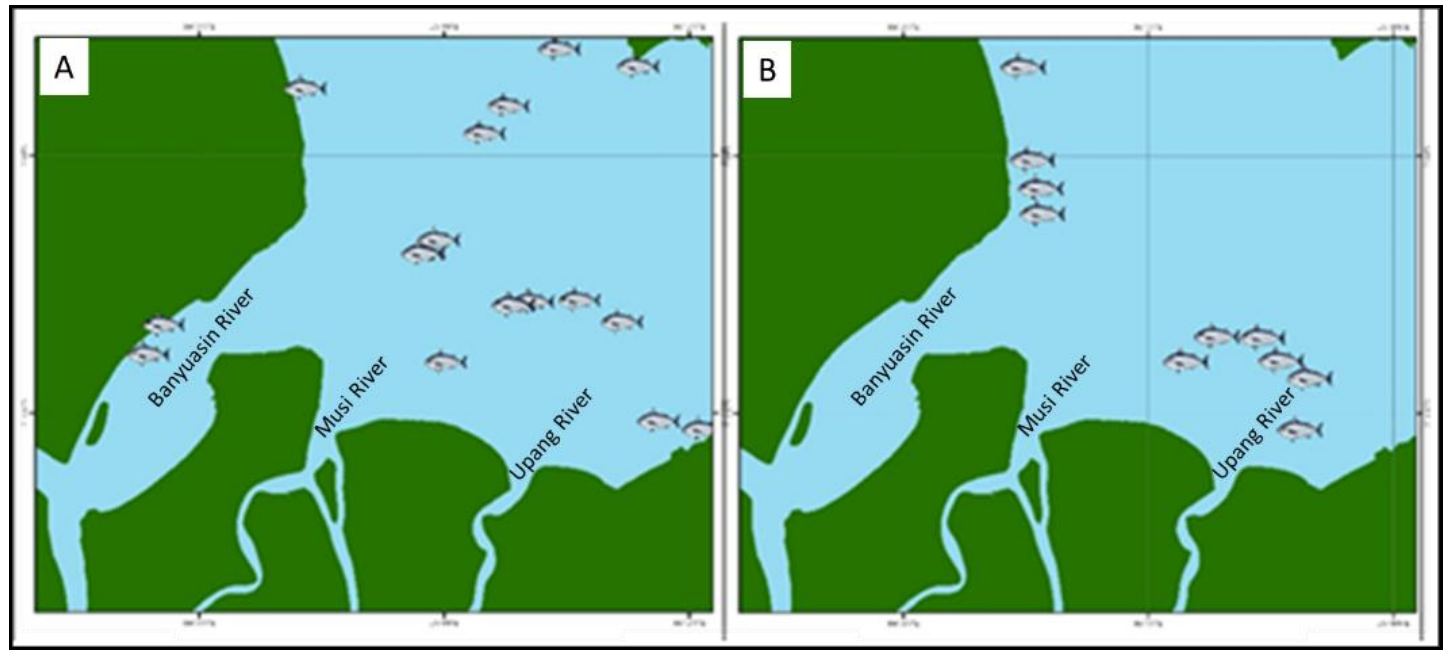

Fig. 4. Distribution of potential fishing zones in the Banyuasin Estuary, A) August 2013; B) August 2017. Source: oceancolor.gsfc.nasa.gov

The fishing potential zone on August 2013 were more than August 2017 (Fig. 4). In August 2013, there were 16 potential fishing zone points, while in August 2017, there were 11 potential fishing zone points. The difference of potential fishing zones points in 
two years was caused by the variability of supporting parameters for fish presence, such as Chlorophyll- $a$ and Sea Surface Temperature. The value of Chlorophyll- $a$ in Banyuasin Estuary had a relatively high value of $>2.0 \mathrm{mg} \cdot \mathrm{m}^{-3}$ in 2013 and 2017. Sea Surface Temperature was ranged between 29 to $31.9^{\circ} \mathrm{C}$ in 2013 and 2017 . This condition showed support for fish survival.

The distribution and abundance of biological resources were inseparable conditions and variations of Chlorophyll-a and Sea Surface Temperature parameters. These parameters had a strong correlation with the aquatic environment (Roy et al., 2018; Lestari et al., 2021; Rozirwan et al., 2021). Fishing ground for fish was not permanent, but it always changed based on water conditions (Selao et al., 2019). Chlorophyll-a and Sea Surface Temperature parameters were fish migration factors. Chlorophyll-a acted as a food source, and Sea Surface Temperature affected marine organisms metabolism and reproduction that could determine feeding ground for fish (Rozirwan et al., 2020; Saragih et al., 2020).

\section{Microalgae Biochemical Content}

Based on Aryawati et al. (2017), the genus Chaetoceros was the dominant taxon, whereas Skeletonema and Thalassiothrix were the dominant genera in the second and third order. Bacillariophyceae class had a high tolerance level to aquatic environmental parameters. The genus Chaetoceros, which was dominated in Banyuasin Estuary, could be cultivated by an open pond or closed pond cultivation. The growth patterns of Chaetoceros at several water volume conditions were presented in Fig. (5).

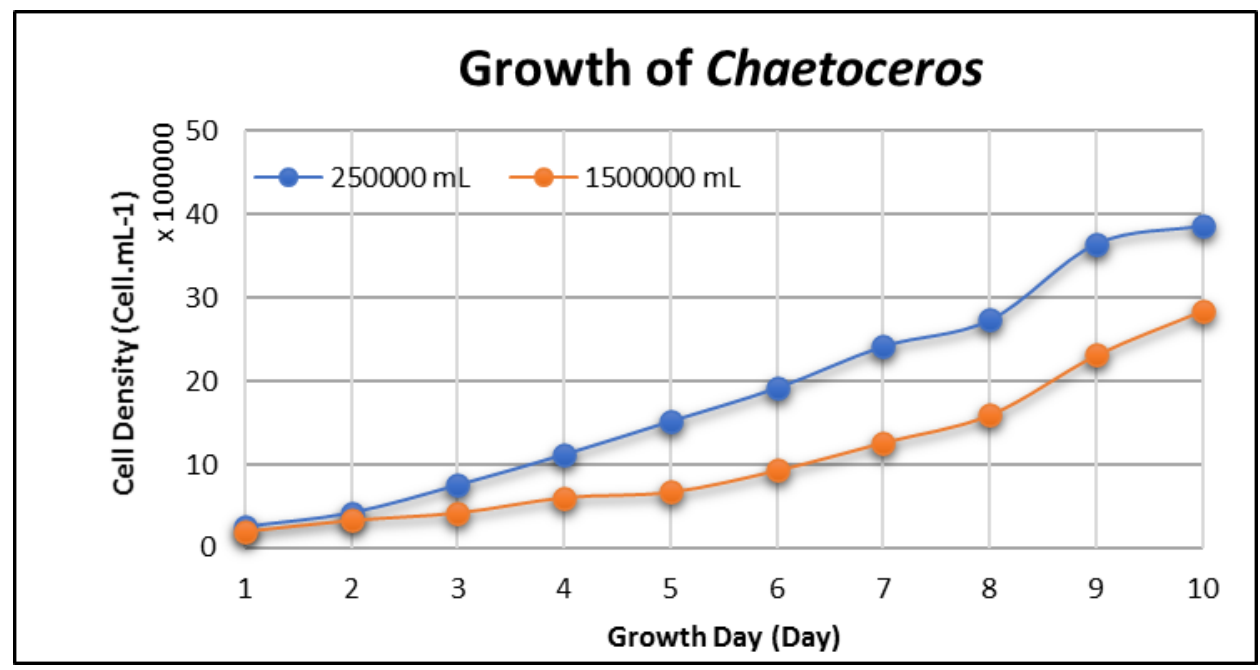

Fig. 5. Chaetoceros Cell Growth

Source: (Ortega-Salas and Reyes-Bustamante, 2014)

The cell density data presented in Fig. (5) showed that Chaetoceros cell growth was speedy. The average cell density in culture media $250,000 \mathrm{~mL}$ was more than of media volume $1,500,000 \mathrm{~mL}$, this finding was due to the difference in the density of the cultured 
cells on the first day. According to (Koyande et al., 2019), the biochemical composition of Chaetoceros was presented in Table 2.

Table 2. Biochemical composition of Chaetoceros

\begin{tabular}{lllll}
\hline Microalgae & & \multicolumn{3}{c}{ Composition (\% dry Biomass) } \\
Genus & Protein & Lipids & Carbohydrate & References \\
\hline Chaetoceros & 36 & 15 & 27 & (Koyande et al., 2019) \\
Chaetoceros (L) & 34.99 & 19.28 & 10.78 & (Rodriguez-Nunez and \\
Chaetoceros $(\mathrm{S})$ & 27.84 & 23.78 & 17.19 & Toledo-Aguero, 2017) \\
\hline
\end{tabular}

L: Logarithmic phase, S: Stationary phase

Based on Table 2, various biochemical data in protein, lipids, and carbohydrates of the Chaetoceros. There was a biochemical content of Chaetoceros in the logarithmic phase and the stationary phase. Microalgae growth phase conditions could affect the value of its biochemical content. So, harvesting techniques with specific objectives were needed when harvesting the cultivated microalgae.

\subsection{Protein}

Proteins were known as building blocks for the human body and were essential macronutrients responsible for the individual's overall growth (Koyande et al., 2019). Alternative protein sources and better production methods were needed to meet consumer demand and meet global protein needs expected to increase.

The microalgae group was considered a viable source of protein. Microalgae for protein production had several advantages over traditional high protein crops in terms of productivity and nutritional value. Microalgae had a higher protein yield per unit area (415 tonnes/ha/year) (Bleakley and Hayes, 2017).

Table 3. Comparison of microalgae protein content and other types of food

\begin{tabular}{ll}
\hline Food types & Protein content (\% Dry Biomass) \\
\hline Meat & 17.4 \\
Fish & 19.2 to 20.6 \\
Chicken & 19 to 24 \\
Peanut & 26 \\
Cheese & 36 \\
Milk powder & 36 \\
Chaetoceros & 27.84 to 36 \\
\hline
\end{tabular}

Source : (Koyande et al., 2019)

The microalgae Chaetoceros which was dominant in the Banyuasin Estuary Waters had a high potential protein content of around 27 to $36 \%$. The protein content of the Chaetoceros was more excellent than several main types of human food such as meat, fish, chicken, and nuts (Table 3). 


\subsection{Lipid}

Many species of microalgae experienced changes in lipid levels according to their growth phase. As shown in Table 2, the lipid levels during the logarithmic phase were $19.28 \%$, and the stationary phase increased to $23.78 \%$. The lipid content of microalgae ranged from 20 to $50 \%$ of the dry biomass (Sun et al., 2018).

Lipid was a substance needed by microalgae as food reserves. Therefore, many processes to obtain these lipids were harvested at a time of nutrient deficiency, and the most appropriate stage was at the fixed period. Apart from harvest, microalgae lipid content could be increased by making environmental conditions different from their natural habitats, such as nutrient restrictions and other external factors, including temperature, salinity, photoperiod, and light intensity (Aziz et al., 2020).

Lipids of microalgae were classified into two groups according to their carbon number. Fatty acids, which had 14 to 20 carbons, were used for biodiesel production. Polyunsaturated fatty acids (PUFAs) with more than 20 carbon atoms were used as health food supplements, especially docosahexaenoic acid (DHA) and eicosapentaenoic acid (EPA) (Sun et al., 2018). The further processing of microalgae lipids could produce vegetable oil to manufacture food and health products (Visca et al., 2017).

\subsection{Carbohydrates}

Carbohydrates of microalgae acted as structural components of cell walls, as storage components and energy providers needed for metabolic processes. Based on Table 2, It was known that the carbohydrate content of the Chaetoceros microalgae was 10.78 to $27 \%$. To carbohydrate production increased, so needed some control overcultivation or environmental conditions such as nutrient deficiencies, salinity levels, light intensity, and many more (Markou et al., 2012).

Carbohydrates were composed of carbon compound components. Microalgae had a large carbon source for biofuels, health supplements, pharmaceutical products, and cosmetics. Microalgae produced several types of sugars such as glucose, fructose, maltose, and rhamnose used by microorganisms in the fermentation process and converted into bioethanol. These were excellent ingredient for produced bioethanol. Some microalgae species were most likely to produced bioethanol because of their higher sugar content. However, carbohydrates in the microalgae biomass were mostly in polymers and needed to be converted into monomer units for easy fermentation by microorganisms to produce bioethanol (Khan et al., 2018).

\section{CONCLUSION}

The distribution of potential fish zones in the Banyuasin Estuary from the two periods was different due to changes in water quality that directly impacted aquatic life. The chlorophyll-a concentration and sea surface temperature are classified as optimal and stable for fish growth. The microalgae of Chaetoceros genus are shown the highest 
abundance of observed area, which is high protein, lipid and carbohydrate content. Further studies will be able to develop the microalgae products of the food, health, pharmaceutical and bioenergy sectors.

\section{ACKNOWLEDGMENTS}

This study was supported by the University of Sriwijaya through Hibah Unggulan Kompetitif 2021 (No. 0107.084/UN9/SB3.LP2M.PT/2021) and Student Creativity Program 2020, Directorate General of Higher Education, Indonesian Ministry of Education and Culture (No. 1686/E2/TU/2020).

\section{REFERENCES}

Armbrust, E. V. (2009). The life of diatoms in the world's oceans. Nature., 459: 185192.

Aryawati, R.; Bengen, D.G.; Prartono, T. and Zulkifli, H. (2017). Abundance of phytoplankton in the coastal waters of South Sumatera. Ilmu Kelautan: Indonesian Journal of Marine Sciences., 22(1): 31-39.

Aziz, M.M.A.; Kassim, K.A.; Shokravi, Z.; Jakarni, F.M.; Liu, H.Y.; Zaini, N.; Tan, L.S.; Islam, A.B.M.S. and Shokravi, H. (2020). Two-stage cultivation strategy for simultaneous increases in growth rate and lipid content of microalgae: A review. Renewable and Sustainable Energy Reviews., 119: 1-15.

Bleakley, S. and Hayes, M. (2017). Algal proteins: extraction, application, and challenges concerning production. Foods Multidisciplinary Digital Publishing Institute., 6(5): 1-34.

Chen, H.; Zhou, W.; Chen, W.; Xie, W.; Jiang, L.; Liang, Q.; Huang, M.; Wu, Z. and Wang, Q. (2017). Simplified, rapid, and inexpensive estimation of water primary productivity based on chlorophyll fluorescence parameter Fo. Journal of plant physiology., 211: 128-135.

Dornhofer, K.; Klinger, P.; Heege, T. and Oppelt, N. (2018). Multi-sensor satellite and in situ monitoring of phytoplankton development in a eutrophic-mesotrophic lake. Science of The Total Environment., 612: 1200-1214.

Dutta, S.; Chanda, A.; Akhand, A. and Hazra, S. (2016). Correlation of phytoplankton biomass (chlorophyll-a) and nutrients with the catch per unit effort in the PFZ forecast areas of Northern Bay of Bengal during simultaneous validation of winter fishing season. Turkish Journal of Fisheries and Aquatic Sciences., 16: 767-777.

Huliselan, N.; Tuapattinaja, M. and Pattimura, U. (2017). Phytoplankton distribution and composition in the waters of Burung and Buntal Islands, Kotania Bay, Western Seram, Maluku, Indonesia. IOP Conference Series Earth and Environmental Science., 89(1): 1-10. 
Khan, M. I.; Shin, J. H. and Kim, J. D. (2018). The promising future of microalgae: current status, challenges, and optimization of a sustainable and renewable industry for biofuels, feed, and other products. Microbial Cell Factories., 17: 1-21.

Koyande, A. K.; Chew K.W.; Rambabu, K.; Tao, Y.; Chu, D.T. and Show, P.L. (2019). Microalgae: A potential alternative to health supplementation for humans. Food Science and Human Wellness., 8(1): 16-24.

Lestari, DA.; Rozirwan, and Melki. (2021). Community structure moluska (bivalvia and gastropoda) in Musi Estuary, South Sumatra. Jurnal Penelitian Sains., 23(1): 52-60.

Li, J.; Cai, Y.; Zhang, P.; Zhang, Q.; Jing, Z.; Wu, Q.; Qiu, Y.; Ma, S. and Chen, Z. (2021). Satellite observation of a newly developed light-fishing "hotspot" in the open South China Sea. Remote Sensing of Environment., 256: 1-12.

Markou, G.; Angelidaki, I. and Georgakakis, D. (2012). Microalgal carbohydrates: an overview of the factors influencing carbohydrates production, and of main bioconversion technologies for production of biofuels. Applied Microbiology And Biotechnology., 96(3): 631-645.

Novais, S. V.; Zenero, M. D. O.; Barreto, M. S. C.; Montes, C. R. and Cerri, C. E. P. (2018). Phosphorus removal from eutrophic water using modified biochar. Science of the Total Environment., 633: 825-835.

Novianti, T. (2019). Study of utilization of Duniliella salina as food fortification material with marine bioeconomic approach. Jurnal Biologi dan Pendidikan Biologi., 3(2): 100-109.

Nur, M. M. A. (2014). The potential of microalgae as a functional food source in Indonesia (overview). Jurnal Eksergi., 11(2): 1-6.

Nurdin, S.; Mustapha, M. A.; Lihan, T. and Zainuddin, M. (2017). Applicability of remote sensing oceanographic data in the detection of potential fishing grounds of Rastrelliger kanagurta in the archipelagic waters of Spermonde, Indonesia. Fisheries Research., 196: 1-12.

Nurhatika, S.; Ermavitalini, D.; Saputro, T. B. and Apriyatmoko, Y. (2018). Biodiversity and characterization of high lipid content microalgae in Porong River Estuary East Java, Indonesia. Biodiversitas Journal of Biological Diversity., 19: 577-582.

Ortega-Salas, A. A. and Reyes-Bustamante, H. (2014). Cultivation of the microalgae Chaetoceros gracilis to feed the rotifer Brachionus plicatilis. UNED Research Journal., 5(2): 189-193.

Parakkasi, P.; Syamsuddin, R. and Tambaru, R. (2020). The impact of seaweed farming on the phytoplankton community structure. Jurnal Ilmu Kelautan Spermonde., 6: $16-25$. 
Pratama, F.; Rozirwan and Aryawati, R. (2019). The dynamics of phytoplankton communities during the day and night in the waters of Sungsang Musi Estuary Village, South Sumatra. Jurnal Penelitian Sains., 21(2): 83-97.

Prince, R. C. and Kheshgi, H. S. (2005). The photobiological production of hydrogen: potential efficiency and effectiveness as a renewable fuel. Critical Reviews in Microbiology., 31: 19-31.

Purwanto, A. D.; Prayogo, T.; Marpaung, S. and Suhada, A. G. (2020). Analysis of potential fishing zones in coastal waters: a case study of Nias Island waters. International Journal of Remote Sensing and Earth Sciences., 17: 9-24.

Ridho, M. R.; Patriono, E. and Mulyani, Y. S. (2020). Relationship of phytoplankton abundance, chlorophyll-a concentration and quality of breech coastal waters, South Sumatra. Jurnal Ilmu dan Teknologi Kelautan Tropis., 12: 1-8.

Rodríguez-Núñez, K. and Toledo-Aguero, P. (2017). Fatty acids profile and nutritional composition of two tropical diatoms from the Costa Rican Pacific Coast. Grasas y Aceites., 68(3): 1-8.

Roy, S.; Putrevu, P.; Tripathi, S. and Pawar, S. (2018). Data mining approach to identify PFZ (Potential Fishing Zone) using oceanographic data. Journal of Data Mining and Management., 3(1): 1-5.

Rozirwan; Iskandar, I.; Hendri, M.; Apri, R.; Azhar, N. and Mardiansyah, W. (2019). Distribution of phytoplankton diversity and abundance in Maspari Island waters, South Sumatera, Indonesia. Sriwijaya International Conference on Basic and Applied Science., 1282: 1-9.

Rozirwan; Apri, R. and Iskandar, I. (2020). Distribution of zooplankton abundance and diversity in the vicinity of Maspari Island, Bangka Strait, South Sumatra, Indonesia. EurAsian Journal of BioSciences., 14: 3571-3579.

Rozirwan; Melki; Apri, R.; Fauziyah; Agussalim, A.; Hartoni and Iskandar, I. (2021). Assessment the macrobenthic diversity and community structure in the Musi Estuary, South Sumatra, Indonesia. Acta Ecologica Sinica., In Press

Santoso, A. B. (2016). The effect of climate change on the production of food crops in Maluku Province. Jurnal Penelitian Pertanian Tanaman Pangan., 35: 29-38.

Saragih, R.; Mannu, D. and Ryan, M. (2020). Forecast fishing areas in the waters of the Kei Islands based on satellite data. IOP Conference Series: Earth and Environmental Science., 517: 1-7.

Selao, A.; Malik, A.; Yani, F. and Mallawa, A. (2019). Remote chlorophyll-a and sst to determination of fish potential area in Makassar Strait waters using MODIS satellite data. IOP Conference Series: Earth and Environmental Science., 270: 1-13. 
Sharabian, M. N.; Ahmad, S. and Karakouzian, M. (2018). Climate change and eutrophication: a short review. Engineering, Technology \& Applied Science Research., 8(6): 3668-3672.

Solanki, H.; Prakash, P.; Dwivedi, R.; Nayak, S.; Kulkarni, A. and Somvamshi, V. (2010). Synergistic application of oceanographic variables from multi-satellite sensors for forecasting potential fishing zones: methodology and validation results. International Journal of Remote Sensing., 31: 775-789.

Spolaore, P. (2006). Commercial applications of microalgae. Journal of Bioscience and Bioengineering., 101: 87-96.

Suhadha, A. G. and Asriningrum, W. (2020). Potential fishing zones estimation based on approach of area matching between thermal front and mesotrophic area. Jurnal Ilmu dan Teknologi Kelautan Tropis., 12: 567-583.

Sun, X. M.; Ren, L.J.; Zhao, Q.Y.; Ji, X.J. and Huang, H. (2018). Microalgae for the production of lipid and carotenoids: a review with focus on stress regulation and adaptation. Biotechnology for Biofuels., 11: 1-16.

Syah, A. F.; Ramdani, L. W. and Suniada, K. I. (2020). Prediction of potential fishing zones for mackerel tuna (Euthynnus sp.) in Bali Strait using remotely sensed data. IOP Conference Series: Earth and Environmental Science., 500:1-10.

Taipale, S. J.; Vuorio, K.; Aalto, S. L.; Peltomaa, E. and Tiirola, M. (2019). Eutrophication reduces the nutritional value of phytoplankton in Boreal Lakes. Environmental Research., 179: 1-13.

Tang, D.Y.Y.; Khoo, K.S.; Chew, K.W.; Tao, Y.; Ho, S.H. and Show, P.L. (2020). Potential utilization of bioproducts from microalgae for the qualityenhancement of natural products. Bioresource Technology., 304: 1-11.

Visca, A.; Caprio, F.A.; Spinellia, R.; Altimaria, P.; Ciccib, A.; Iaquaniellob, G.; Toroa, L. and Pagnanelli, F. (2017). Microalgae cultivation for lipids and carbohydrates production. Chemical Engineering Transactions., 57: 127-132.

Wicaksono, V. A.; Hasan, Z.; Gumilar, I. and Dewanti, L. P. (2019). The determination of shortfin scad (Decapterus sp.) potential fishing area with chlorophyll-a distribution in Pekalongan Sea, Central Java, Indonesia. World Scientific News., 119: 111-124.

Wijesekera, H. W.; Shroyer, E.; Tandon, A.; Ravichandran, M.; Sengupta, D.; Jinadasa, S.; Fernando, H. J.; Agrawal, N.; Arulananthan, K. and Bhat, G. (2016). ASIRI: An ocean-atmosphere initiative for Bay of Bengal. Bulletin of the American Meteorological Society., 97: 1859-1884.

Zhang, Z. and Wang, J. (2020). Phytoplankton, dissolved oxygen and nutrient patterns along a eutrophic river estuary continuum: observation and modeling. Journal of Environmental Management., 261: 1-12. 